\title{
How does Cultural Norms Influence Entrepreneurial Intention? A Cross Cultural Study
}

$\begin{array}{r}\text { José Carlos Sánchez-García } \\ \text { jsanchez@usal.es }\end{array}$
Universidad de Salamanca, Spain
Alexander Ward Mayens
alexander.ward@usal.es
Universidad de Salamanca, Spain
Gioconda Vargas Morúa
gvargasm@usal.es
Universidad de Salamanca, Spain
Jenny Linette Flórez Daza
jflorez@usal.es
Universidad de Salamanca, Spain
Brizeida Hernández Sánchez
brizeida@usal.es
Universidad de Salamanca, Spain

\begin{abstract}
Entrepreneurial Intention is commonly attributed to the interaction of cultural values and attitude; however, cultural values vary according to the context in which they are developed. The following study intends to show how Subjective Norms affect intentions of self-employment, as both, a direct factor and mediated through attitudinal values: Perceived Behavioral Control and Desirability, within a cross-cultural framework. A sample of 736 students from four different countries: Spain, Portugal, Mexico and India were used. Results yielded a direct relationship between Subjective Norm and Intention in all countries, except India. When mediated through attitude, the relation becomes stronger, even more when it's through Desirability, except in Portugal, which the relationship is stronger directly through Social Norms. India does not show a relationship between Perceived Behavioral Control and Intention. Conclusions show that the influence of culture on intention, effectively, varies by context.
\end{abstract}

Keywords: Entrepreneurship, Psychology, Intention, Culture, Subjective Norm. 
Sánchez-García, J.C., Ward Mayens, A., Vargas Morúa, G., Hernández Sánchez, B. (2018). How does Cultural Norms Influence Entrepreneurial Intention? A Cross Cultural Study. Journal of Business, Universidad del Pacífico (Lima, Peru) Vol.10 (1): 52-69

\section{Introduction}

The benefits that entrepreneurship offers to society have become evident through history, mainly due to its demand for innovation, development and creation of employment opportunities, however, the role that entrepreneurship plays in improving those conditions also acts in a reciprocal way: society plays in forming the conditions that creates entrepreneurs. For this reason, it's important to understand how the environment is optimized to effectively promote entrepreneurial developement, specifically, its intention. Entrepreneurial intention, although widely studied (eg, Carr \& Sequeira 2007, Kautonen, Luoto \& Tornikoski 2010, Tornikoski, Erno \& Kautonen 2009), is still far from a complete understanding on how its dynamics work in different contexts and countries.

Bretones and Silva (2009), believe the study of culture and entrepreneurial behavior includes that of social and economic aspects related with specific values and beliefs that would influence behavior. This differentiates people from diverse backgrounds and territories, including in the field of organizations. Hofstede (1980) defines culture as an aggregation of shared values, beliefs, norms and expected behaviors; this study will be heavily emphasized on norms.

In the present study, entrepreneurial intention will be analyzed taking as reference a sample of countries with different development contexts, considering each comprises a different reality in their process of promoting and employing entrepreneurial values. For example, India has high levels of poverty, approximately 350 million people (Bureau 2015), where of every three; one lacks basic needs, including employment and education. In some cases, may even extend to the point of illiteracy (Shaw \& de Bruin, 2013), however, it has a Total of Entrepreneurial Activity (TEA) of 10.6, matching competitively with other countries of Asia and Oceania (GEM, 2016). Considered a country with noticeable collectivist values, Tiwari, Bhat and Tikoria (2017) found a significant relationship between its subjective norm and entrepreneurial intention. Similarly, a study by lakovleva, Kolvereid, and Stephan (2011), investigated the relationship of entrepreneurial intention between emerging and developed countries, which India participated, demonstrating that the relationship of attitudes and perceived control have less intensity in entrepreneurial intention within developing countries than in developed ones.

Contrasting among other emerging economies, Mexico leads among other Latin American countries in entrepreneurial activity (GEM, 2016) and in 2015 showed a TEA of $21 \%$ (GEM 2015). Despite this, Kantis, (2002) points financial restriction and identification of regulatory obstacles (taxes, procedures, registration costs) as highlights among difficulties for startups; while, showing institutional support and a tendency to rest in close relationships (relatives, friends and acquaintances) as a strength.

On the other hand, developed countries can also show different contexts that impact entrepreneurial feasibility, pointing to different challenges. In the case of Portugal and Spain, there is a comparable situation with respect to entrepreneurial activity, with a TEA of $8.2 \%$ (GEM, 2013) and 5.7\% (GEM, 2015) respectively, which places them below other countries in Europe. Several studies have researched on how attitudes and environment interact within these two countries in promoting entrepreneurship. Sampedro, Fernández-Laviada and Crespo, (2013) found that students in Spain show a positive relationship in how they perceive social support towards entrepreneurial behavior, as well as their willingness to endeavor within them. Also, results showed students consider existing formation as acceptable, but access to funding limited. 
At a comparative level, Portuguese university students are more prone to selfemployment than those in Spain (Sánchez \& Yurrebaso, 2008), considering desirable self-employment and perceiving favorable social support towards entrepreneurship. Another study found that students from Spain (Extremadura) recognize entrepreneurship presently as more accessible than decades ago, while those in Portugal (Beira) consider it more difficult nowadays. However, it is the students of Portugal (Beira) that often start a business (Díaz-casero, Ferreira, Hernández Mogollón, \& Barata Raposo, 2012).

These arguments demonstrate the relevance of pursuing a deeper understanding of the role played by prior exposure on the process of enterprising in a more systematic way, specifically, in its intention, as well as a need to expand on their relationship by context: how it can change by variables such as the individual and environment.

The following study aims to answer these following questions: (1) How does a country's culture influence the desirability and perceived control of students and their intention to start a business?; (2) Is the effect of culture on entrepreneurial intention greater when mediated by desirability and perceived control? (3); What is the difference between the entrepreneurial intention of students from different socio-cultural backgrounds, when perceived control and desirability act as mediating variables?; and (4) To what extent does perceived control and desirability affect entrepreneurial intention in students, when different socio-cultural backgrounds are taken into account?

Based on these goals, the main objective of this research is to identify the effects of subjective norm on entrepreneurial intention during the process, both directly and indirectly, using as mediating variable desirability and perceived control. Participants in this study correspond to a sample of university students from two developing countries (Mexico and India), and two developed countries (Spain and Portugal). The analysis was carried out with each country separately, then compared among them in order to contrast the influence of each variable on entrepreneurial intention.

\section{Theoretical Background}

\section{Entrepreneurial Intention}

According to Krueger, (1993), entrepreneurial intention is a state of mind that people have, opting for the creation of a new company or the creation of value within existing organizations; the commitment to perform the necessary behavior to carry out an entrepreneurial initiative. Authors such as Cabana-Villca, Cortes-Castillo, Plaza-Pasten, Castillo-Vergara, Alvarez-Marin, (2013) and Krueger, (1993) consider intentions as the best predictor of planned behavior, such as starting a business. The findings of several studies have found a positive effect between intention and entrepreneurial behavior (Ajzen, 1991, Fayolle, Gailly \& Lassas-Clerc, 2006, Homer \& Kahle, 1988, Jogiyanto, 2007, Kolvereid, 1996, Schwarz, Wdowiak, Almer- Jarz, Breitenecker, 2009; Tkachev \& Kolvereid, 1999).

The following are two of the most researched models, which act as backbone of this study: Theory of Planned Behavior and Shapero's model of the Entrepreneurial Event, which support the relationship between entrepreneurial behavior and entrepreneurial intention, in order to answer the questions posed in the present study: 
The Theory of Planned Behavior (TPB) (Ajzen, 1991) is based on intentions people possess to carry out their behavior, and these can be predicted by the following elements: attitudes towards behavior, subjective norms and perceived behavioral control. Attitude towards behavior is defined as the degree in which a person has a favorable or unfavorable evaluation or assessment of the behavior in question (Ajzen, 1991). The second, subjective norm, refers the perceived social pressure whether to carry out the behavior or not (Ajzen, 1991), in other words, the opinion of how third parties - such as family, friends or teachers - influences the individual. The third is the degree of perceived behavioral control that, according to Ajzen (1991), is the viability of performing a perceived behavior, since it is not always completely subject to the person's will (Ajzen, 2002). Ultimately, within the TPB (Ajzen, 1991), its core is the intention of people to perform a certain behavior. Intentions, therefore, capture the motivational factors that influence a behavior, as well as the amount of effort they are willing to exert to achieve it (Ajzen, 1991).

Shapero's model of the Entrepreneurial Event (SEE) (Shapero \& Sokol, 1982) introduces two aspects that influence the creation of companies: desirability and feasibility. Both aspects are products of the cultural and social environment that ultimately determine entrepreneurial behavior. Shapero and Shokol (1982) examine the concept of desirability using information about the family, circle of friends, ethnic group, among others. In terms of feasibility, they point out the importance of the individual's ability to obtain resources in a way that makes enterprising possible. Shapero and Shokol (1982), proposed three phases: the first, in which a series of events trigger or predispose entrepreneurship to happen; the second, which calls for desire, transforming a potential entrepreneur into a possibility and the third, action, in which the individual finally decides to create its business.

\section{Subjective Norm}

Subjective norm (NS) is the second predictor of intention, and refers to the perceived social pressure to carry out or not a behavior (Ajzen, 1991); it corresponds to exogenous variables, such as the expectations or opinions of others (Shapero \& Shokol, 1982). Nilsson, Borgstede, and Biel (2004) claim that NS also accounts for a person's belief in referring to the influence of others to behave in a certain way and meet their expectations. In other words, the tendency of an individual to consider the perceptions of others, such as significant persons, families, friends or communities as a tool to guide them to undertake or not decisions. Rhodes and Courneya (2003) consider that this construct is also capable of mediating entrepreneurial behavior. Effectively, multiple studies have shown a positive effect between subjective norm and entrepreneurial behavior (Armitage \& Conner, 2001; Miner, 2001; Rimal \& Real, 2003), particularly, in entrepreneurial intention (Ajzen, 1998, 1991, 2002; Fisbein; \& Ajzen, 1975, Guido, Marcati \& Peluso, 2011, Liñan \& Chan 2009, Rhodes \& Courneya, 2003, Shook \& Britanu, 2008, Solesvick, Westhead, Kolvereid \& Matlay, 2012, Schwarz et al., 2009, Tkachev \& Kolvereid, 1999;), as well as effecting it indirectly (Paço, Ferreira, Raposo, Gouveia \& Dinis, 2011). Although, contrasting results have been found as well, such as the meta-analysis carried out by Armitage and Conner (2001), in which they conclude that NS is a weak predictor, 
Sánchez-García, J.C., Ward Mayens, A., Vargas Morúa, G., Hernández Sánchez, B. (2018). How does Cultural Norms Influence Entrepreneurial Intention? A Cross Cultural Study. Journal of Business, Universidad del Pacífico (Lima, Peru) Vol.10 (1): 52-69

and in some cases, not significant at all (Autio, Keeley, Klofsten, Parker \& Hay, 2001; Krueger, Reilly, \& Carsrud, 2000; Liñan, 2008).

Evidence shows that self-employment outcomes are significantly affected by factors such as individual skills, family background, employment status, liquidity constraints and ethnic enclaves (Le, 1999). This indicates that entrepreneurs are influenced by the closest environment that surrounds them, family being the only social institution in which all entrepreneurs are rooted (Aldrich \& Cliffb, 2003). Some research indicates that the experience of students with family businesses provides them with more developed positive attitudes towards business (Harris, \& Gibson, 2008, Mohamed, Rezai, Mad \& Muhammad, 2012), as well as greater influence and predisposition (Fayolle \& Klandt, 2006). However, others suggest that this previous entrepreneurial exposure may also be negative (Zhang et al., 2014).

With respect to culture, Hofstede (1980) refers to it as "the collective programming of the mind that distinguishes the members of one human group from another ... [e] includes value systems" (p.25). Culture, as the underlying system of values of a specific group or society, motivates the individuals of a certain society to engage in behaviors that may not be evident in others (Mueller \& Thomas, 2000) such as entrepreneurial behavior, considering there are differences in values and cultural beliefs from one country to another.

In summary, literature shows the existence of influences of the subjective norm (relatives, friends or close persons) towards the entrepreneurial intention, and that the culture associated with the subjective norm in which a person develops can influence in greater or lesser way entrepreneurial intention.

\section{Perceived Behavioral Control}

Perceived Behavioral Control is the third factor for predicting intention, and is the feasibility of performing a perceived behavior, as factors concerning the success of its execution may not be entirely up to the individual (Ajzen, 2002). Shapero and Shokol (1982), on the other hand, indicate that business intentions are derived from the perception of feasibility, as well as convenience, since people usually choose to adopt behaviors that they think they will be able to control and dominate (Fayolle \& Klandt, 2006), so that their behaviors are influenced by the confidence they have in their ability to carry them out (Ajzen, 1991).

Krueger and Carsrud (1993) state that "perceived self-efficacy or control for business behaviors are influenced by the acquisition of management tools and exposure to business situations" (page 326). In this case, beliefs of control are based on past experiences of entrepreneurial behavior, as well as the influence that third-party information has on it, such as the culture in which it was developed.

Therefore, support of political, social and business leaders could be a fundamental factor for the development of business activity (Krueger \& Brazeal, 1994), since its support provided through incentives encourages the formation of companies and makes more likely that entrepreneurs perceive their chance of self-employment as something 
Sánchez-García, J.C., Ward Mayens, A., Vargas Morúa, G., Hernández Sánchez, B. (2018). How does Cultural Norms Influence Entrepreneurial Intention? A Cross Cultural Study. Journal of Business, Universidad del Pacífico (Lima, Peru) Vol.10 (1): 52-69

possible. However, it is assumed that not all cultures behave in the same way and, that, from one country to another, different situations and opportunities are offered, specific to each.

\section{Desirability}

Desirability refers to the desire and attraction that a person feels when initiating an entrepreneurial activity, for which he makes important personal sacrifices and place it before any other opportunity or activity that avoids its achievement (Sanchez, 2010). Peterman and Kennedy (2003) point out that the degree of change in the perception of desirability and feasibility are positively related to previous experience, therefore, it is considered that the environment in which it operates will be important for the development of entrepreneurial intentions. According to the model of the Entrepreneurial Event of Shapero and Shokol (1982), intentions are derived from the perceptions of feasibility and desirability. That is, an individual who perceives a business opportunity (which can be given by their environment or culture), will analyze it within the framework of these two factors and, once confirmed, will lead to business creation.

\section{Hypotheses for Study}

It's important to stress that entrepreneurs can be influenced by the closest environment that surrounds them, and the more favorable the expectation and social pressure perceived, referring to NS, the greater the influence on behavior (Ajzen, 1991). It should also be noted that the desire felt by the entrepreneur to carry out a behavior, and the perception he feels of being able to carry out the activity, will ultimately influence his intention.

Shapero and Shokol (1982), suggest that there must be a trigger, which the desirability and feasibility to act on opportunities derives from. For the purposes of this study, cultural norms are proposed as one of these. Depending on the place and its conditions, an entrepreneurial mindset will be either promoted or thwarted, potentially affecting how a person will both value its wishes and the feasibility to start a business. Thus, while cultural norms may possess a considerable influence, it could also be fundamental, and with perhaps a stronger effect, how the person itself weights its desire and control on the situation, forming ultimately his intention to act upon enterprising. The hypotheses proposed for this study are as follows:

H1: Subjective Norm directly influences Entrepreneurial Intention.

H2: Subjective Norm influences Entrepreneurial Intention through Perceived Behavioral Control.

H3: Subjective Norm influences Entrepreneurial Intention through Desirability.

H4: The effect of Subjective Norm on Entrepreneurial Intention is greater when influenced by Desirability and Perceived Behavioral Control. 
Given the previous hypotheses, the following model is presented in Figure 1:

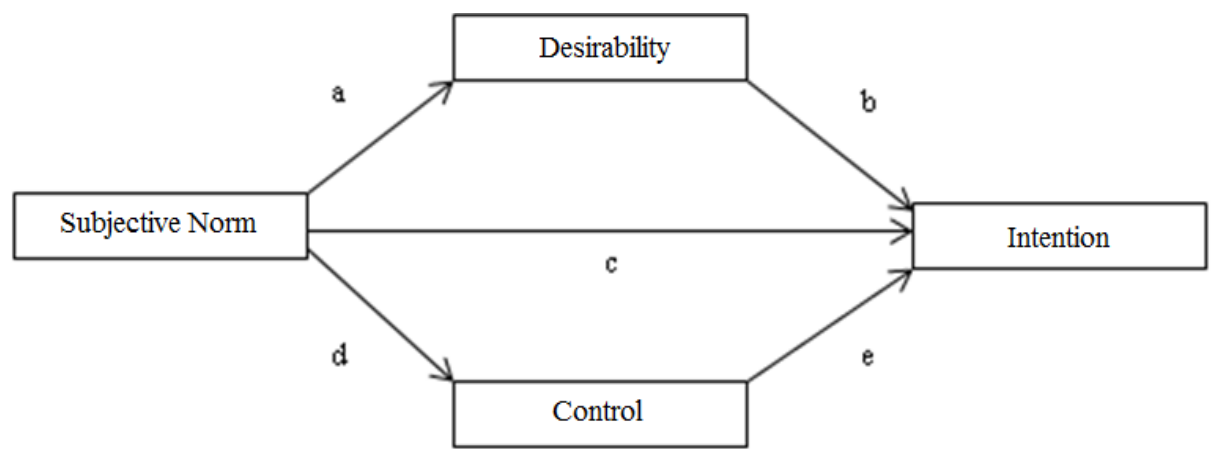

Figure 1. Proposed model on the effect of Subjective Norm on the Entrepreneurial Intention, with two mediating variables.

\section{Method}

\section{Sample}

A sample of 736 university students (from bachelor to doctorate), linked to various areas of knowledge was used. Table 1 details samples by country

Table 1. Sample Description

\begin{tabular}{lccccccc}
\hline & \multicolumn{3}{c}{ Age } & \multicolumn{4}{c}{ Gender } \\
\hline Country & Total & Range & Mean & \multicolumn{2}{c}{ Male } & \multicolumn{2}{c}{ Female } \\
Spain & 253 & $17-40$ & 21,20 & 71 & $28,1 \%$ & 182 & $71,9 \%$ \\
Portugal & 104 & $17-60$ & 25,98 & 41 & $39,4 \%$ & 63 & $60,6 \%$ \\
México & 254 & $18-59$ & 21,97 & 111 & $43,7 \%$ & 143 & $56,3 \%$ \\
India & 125 & $18-51$ & 21,83 & 112 & $89,6 \%$ & 13 & $10,4 \%$ \\
Total & 736 & & & 335 & $46 \%$ & 401 & $54 \%$ \\
\hline
\end{tabular}

The sample was collected through collaboration with teachers from universities of each respective country, which administered a questionnaire designed to measure university student's potential (Sánchez, 2016) through both means, digital and by paper.

Instrument

Four scales from the questionnaire (Sánchez, 2016) were used, specifically, containing items that measure Intention (6), Subjective Norm (5), Perceived Behavioral Control (6) 
and Desirability (8), for a total of 25 items. For its analysis, and to test the hypotheses of the proposed model, the macro PROCESS in SPSS 23 (Hayes \& Scharkow, 2013) was used to analyze the direct and indirect effects between the variables.

The scales used to measure the variables are interval metrics (1-5 Likert scales), which are detailed below:

Entrepreneurial Intention- Corresponds to the dependent variable with six items. Questions such as "I am ready to do anything as an entrepreneur, or, I have thought very seriously about starting a business" were asked.

Subjective Norm- Corresponds to the independent variable. Five items are considered, which ask if the family, friends, colleagues and culture view the business activity favorably.

Desirability- Corresponds to the first mediating variable; composed of eight items, comprising of questions related to their desire and preference for business activity.

Perceived Behavioral Control- Corresponds to the second mediating variable composed of 6 items, in which questions are asked related to their ability to control the processes of venture creation.

Country- As control variable.

Analysis and Procedure

For the analysis of the hypotheses according to the proposed model, the macro PROCESS was used in SPSS 23 (Hayes, \& Scharkow, 2013, Hayes \& Preacher, 2014).

Bootstrapping was used (Hayes, 2013) because of its facilitation of statistical inference without raising assumptions about the normality of the data or requiring large samples, since it constitutes a method of resampling $(10,000$ samples in this case) that is used to approximate the distribution of a statistic (the coefficient of regression that estimates the indirect effect) and builds the confidence intervals (IC) to make a statistical decision about the significance of the observed effect (Hayes, 2013). It is considered that an indirect effect $(\mathrm{ab})$ is statistically significant if the established confidence interval $(95 \%$ IC) does not include the zero value. If the zero value is included in said confidence interval, the null hypothesis that the indirect effect is equal to zero cannot be rejected, that is, there is no association between the variables involved (Hayes, 2013).

Therefore, the analytical strategy used was based on this procedure with the objective of evaluating the effect of desirability and perceived control over entrepreneurial intention, for which model 4 of Bootstrapping by Hayes (2013) was used, proposing a model with two mediating variables.

\section{Results}

Scale reliability was realized by country. Results obtained are shown in Table 2.

Table 2. Scale Reliability analysis, by country

\begin{tabular}{lccccc}
\hline \multicolumn{1}{c}{ Cronbach's $\boldsymbol{\alpha}$} & Items & Spain & India & Mexico & Portugal \\
\hline \hline $\begin{array}{l}\text { Entrepreneurial } \\
\text { Intention }\end{array}$ & 6 & 0,949 & 0,941 & 0,940 & 0,934
\end{tabular}


Sánchez-García, J.C., Ward Mayens, A., Vargas Morúa, G., Hernández Sánchez, B. (2018). How does Cultural Norms Influence Entrepreneurial Intention? A Cross Cultural Study. Journal of Business, Universidad del Pacífico (Lima, Peru) Vol.10 (1): 52-69

\begin{tabular}{llllll} 
Subjective Norm & 5 & 0,640 & 0,734 & 0,791 & 0,762 \\
Desirability & 8 & 0,928 & 0,930 & 0,931 & 0,884 \\
Perceived Control & 6 & 0,876 & 0,815 & 0,909 & 0,936 \\
\hline \hline
\end{tabular}

This analysis concludes that each of the scales presents an adequate internal consistency, and is capable of providing the required information.

The most significant results of the study are presented below (Table 3 ) which are based on the hypotheses and proposed model (see figure 1). The variables were assigned as:

Independent Variable (X) Subjective Norm

Dependent Variable (Y) Entrepreneurial Intention

Medidator 1 (M1) Desirability

Medidator 2 (M2) Perceived Control

Table 3. Subjective Norm's effect on Entrepreneurial Intention, including effect through mediator variables

\begin{tabular}{|c|c|c|c|c|c|}
\hline Inidrect Effect & Path & $\beta$ Spain & $\beta$ Mexico & $\beta$ India & $\begin{array}{c}\beta \\
\text { Portugal }\end{array}$ \\
\hline Subjective Norm / Desirability & $\mathrm{a}$ & 0,3684 & 0,3508 & 0,3033 & 0,2320 \\
\hline Desirability / Entrepreneurial Intention & $\mathrm{b}$ & 0,7090 & 0,7157 & 0,8342 & 0,8404 \\
\hline Subjective Norm / Perceived Control & d & 0,4364 & 0,4755 & $0,1126 \times$ & 0,4516 \\
\hline $\begin{array}{l}\text { Perceived Control / Entrepreneurial } \\
\text { Intention }\end{array}$ & e & 0,3208 & 0,2499 & 0,3503 & 0,1757 \\
\hline Direct Effect & $\mathrm{c}^{\prime}$ & 0,1589 & 0,1059 & $-0,0447 x$ & 0,4067 \\
\hline $\begin{array}{l}\text { Total Effect: Subjective Norm }-> \\
\text { Intention }\end{array}$ & $a b+d e+c^{\prime}$ & 0,5601 & 0,4758 & 0,2478 & 0,6810 \\
\hline Total Model Effect & $\overline{R^{2}}$ & 0,1001 & 0,1581 & 0,0383 & 0,2156 \\
\hline Sample & & 253 & 254 & 125 & 104 \\
\hline
\end{tabular}

Notes: $p<0,05$ with exception of "x"; non-standarized coefficients; re-sampling number: 10000; Confidence interval: 95\%. Model 4 of Bootstrapping used (Hayes, 2013).

As shown in Table 3, there is a relationship between culture and entrepreneurial intention, and except for two results, all effects were statistically significant. 
Indirect Effect: These occur when the mediating variables are used both for desirability and for perceived behavioral control. In the countries of Spain, Mexico and Portugal, the indirect effect of these mediating variables is statistically significant, given that the confidence interval does not include the zero value, with a confidence index of $95 \%$. In the specific case of India, the mediation given by the desirability to start a business is statistically significant, however, not when mediated through perceived behavioral control, since the confidence interval includes the zero value, nullifying the hypothesis (Ho: $\beta=0$ ) therefore, cancels the mediational relationship.

On the other hand, the sign of the beta coefficients is positive, so it can be concluded that subjective norm produces a positive effect on students' desire to start a business (M1), which in turn produces a positive effect on entrepreneurial intention. That is, cultural norms can positively influence a student so that it shows a desire of self-employment, which in turn motivates his intention to endeavor on this behavior. Similarly, but to a lesser extent, cultural norms positively affects the perception of control that students have over entrepreneurial activity, so it can be said that the indirect effect is partially explained by the mediating variables of desirability and perception of control over entrepreneurial activity.

Direct effect. In the countries of Spain, Mexico and Portugal there is a direct and statistically significant relationship between subjective norm and entrepreneurial intention. These results, however, are not shared with India, where there was no significant direct relationship (see table 3).

When adding the indirect effects, - of desirability (ab) plus perceived control (of) -, and comparing them with the direct effect, -subjective norm on the intention (c) -, is found that the indirect effect is greater than the direct effect, with the exception of Portugal (See table 4). This indicates that the desire and control that students feel to start a business is a variable that partially mediates the relationship with intention.

Thus, in all countries, except Portugal, subjective norm exerts an influence, on both, the desire and the perceived control of students in their entrepreneurial intentions. This indirect effect is greater than the effect subjective norm exerts directly on intention.

The total effect. As observed in the results, the greatest total effect of subjective norms on entrepreneurial intention, mediated by desirability and perceived control, is obtained by Portugal, followed by Spain, Mexico, and finally India. The total effect multiplies each part of the indirect effect, and then adds both: results obtained and direct effect. In the specific case of India, one of the relationships is not statistically significant, making its total effect lesser than the rest.

In Table 4, the acceptance or rejection of the hypotheses presented is shown by country:

Tabla 4. Hypothesis acceptance or rejection.

\begin{tabular}{lccccc}
\hline Hypothesis & & Spain & Mexico & India & Portugal \\
\hline $\begin{array}{l}\text { Direct Effect (c') } \\
\begin{array}{l}\text { Indirect Effect } \\
\text { H1 }\end{array}\end{array}$ & A & A & R & A \\
$\begin{array}{l}\text { Mediator: Perceived Control } \\
\text { (de) }\end{array}$ & H2 & A & A & R & A \\
Mediator: Desirability (ab) & H3 & A & A & A & A
\end{tabular}


Sánchez-García, J.C., Ward Mayens, A., Vargas Morúa, G., Hernández Sánchez, B. (2018). How does Cultural Norms Influence Entrepreneurial Intention? A Cross Cultural Study. Journal of Business, Universidad del Pacífico (Lima, Peru) Vol.10 (1): 52-69

$\begin{aligned} & \text { Total Indirect Effect }>\text { Direct } \\ & \text { Effect }\end{aligned}$

Note: A: Hyptohesis Accepted; R: Hypothesis Rejected.

As explained above, there is a direct relationship between subjective norm and entrepreneurial intention in all countries, except India, where this effect is not statistically significant, thus accepting $\mathrm{H} 1$ in all countries, except for India, where that hypothesis is rejected.

There is also an indirect effect between subjective norm and entrepreneurial intention when mediated by the perception of the student's control of the behavior. This relationship is observed in all countries, except for India, where it is not statistically significant, thus, $\mathrm{H} 2$ is accepted in all countries except India. Regarding the effect mediated by the desire of a student to start a business, this relationship is statistically significant; therefore, $\mathrm{H} 3$ is accepted in all countries.

Lastly, the indirect effect, mediated by desirability and perceived control, is greater than the direct effect with the exception of Portugal, whereby $\mathrm{H} 4$ is accepted in all countries with the exception of Portugal.

\section{Conclusions and Discussion}

It is assumed that entrepreneurial behavior is given by many factors, and that these change over time (Le, 1999). Among these, culture itself can be considered as a category within subjective norm, since the community also exerts influence on people. Therefore, according to this assumption, it was examined how culture affects entrepreneurial intention, both directly and/or indirectly.

It was to be expected that there would be differences between cultural norms between the countries studied, and that those differences would affect, to a greater or lesser extent, entrepreneurial intention. The results obtained show these differences, and the magnitude of the effects are detailed below:

The cultural norms of Spain, Mexico and Portugal, affect entrepreneurial intention in students, both directly and indirectly. These results coincide with those of Ajzen, (1998,1991,2002); Fisbein and Ajzen, (1975); Guido et al., (2011); Liñan and Chan (2009); Rhodes and Courneya, (2003); Scholten, Kemp and Omta, (2004); Schwarz, et al., (2009); Shook and Britanu, (2010); Solvesik et al., (2012); and Tkachev and Kolvereid, (1999), where in their studies the positive effect between subjective norm and entrepreneurial behavior is considered. However, this does not happen with India, adding to the pool of other studies that have not found a significant relationship between subjective norm and intention (Autio, et al., 2001; Krueger et al., 2000; \& Liñán, 2008, Tiwari, Bhat \& Tikoria 2017). This study was also able to determine that the total indirect effect is higher than the direct effect in the countries at study, with the exception of Portugal. That is, cultural norms somehow affect students desire and perceived 
behavioral control on venture creation, and, in addition, the effect of these variables is greater than if cultural norms acted by itself.

India, despite being an emerging country, whose economy is currently growing the most (OECE, p27), students thinking generally lean towards paid jobs, partly because of the risk aversion attitude found in their society (Paul, Hermel \& Srivastava, 2017), diminishing their intentions of self-employment. Results show that Indian students have positive views entrepreneurship, however, they will generally seek long-term, secure employment, such as government jobs, as they do not receive substantial social security benefits (Paul and Gupta 2014). Additionally, the political situation in India is conflictive (OECE, 2016), so it is expected that students' desire for venture creation is statistically significant, but because of this, the feeling of a possibility for starting a business not being presently feasible (Paul \& Gupta 2014 Paul, et al., 2017) as well. A possible line of future research could be to explore the prospect of self-employment vs. paid job in India.

Facing these results, authors such as Manolova, Eunni, and Gyoshev, (2008); Hechavarria and Reynolds, (2009); and Williams, (2009), consider that entrepreneurial behavior, in any emerging society, must evaluate their lack of information, developed institutional structures and level of uncertainty. These factors could lead to a reduction in entrepreneurial opportunities, given that business activity becomes more risky and complex, ultimately affecting motivation for venture creation.

In the case of Portugal, where the direct effect is greater than the indirect effect (culture has a greater weight on entrepreneurial intention than the person's attitude), could be potentially explained by student's low control perception, thus, feasibility, to engage in entrepreneurial activity, opting for other activities that would give them greater outcomes (Franco, Haase, \& Lautenschläger, 2010). However, environment and family influence have a chance of affecting desire to start a business. Additionally, the government promotes a transformation of the educational model, so that students may perceive that their culture favors entrepreneurial activity, although these results seem more ideological than empirical. (Franco, et al., 2010).

Results obtained in Spain and Mexico show a certain similarity, both in the direct and indirect effect, on entrepreneurial intention, however, both countries show different realities. One possible explanation in Spain is that enterprising is desired as a measure to counteract the high levels of unemployment caused by the country's recent economic crisis, along with a strong relationship of entrepreneurship with feelings of personal enjoyment and satisfaction (Bosma, Acs, Autio, Coduras \& Levie, 2008; Uslay, Teach, \& Schwartz, 2012). Although the country's high fear of failure (Bosma, et al., 2008) could explain desirability's stronger influence than perceived behavioral control, considerable reduction of this fear over the years could explain at the same time how the social valuation towards entrepreneurship has improved (GEM, 2015).

Regarding Mexico, influence that stems from friends, colleagues and overall collective, combined with governmental support on the promotion of business activities, gives them a certain level of confidence and control over the achievement of venture creation. (Prieto, Wang, Hinrichs, \& Aguirre-Milling, 2010). Likewise, their own beliefs that becoming self-employed are signs ingeniousness and perseverance, along with few 
decent employment alternatives in the labor market, intensify the desire to try to start a business (Prieto, et al., 2010). These two ideas coincide with the results obtained in this study, since both the desirability and the perceived behavioral control mediate the relationship between culture and entrepreneurial intention.

The comparison of these four countries highlights Portugal as the country that has the greatest total effect between cultural norms and entrepreneurial intention, mediated by desirability and perceived behavioral control. Interestingly, although they do not have high levels of perceived control to carry out self-employment, their high desire, coupled with the support perceived by society, identify the students of Portugal with the greatest entrepreneurial intentions. Future potential research would be to follow in a long-term study Portuguese student's success of venture creation, as well as exploring which cultural aspects most influence their intention.

In conclusion:

There exists a direct relationship between subjective norm and entrepreneurial intentions, especially in Mexico, Spain and Portugal.

There exists an indirect relationship between subjective norms and entrepreneurial intention, mediated by the desirability of venture creation, in all countries studied.

There is an indirect relationship between subjective norm and entrepreneurial intention, mediated by perceived control, in all countries studied, with the exception of India.

The total indirect effect is greater than the direct effect on the relationship between subjective norms and entrepreneurial intention, with the exception of Portugal, where the direct effect is greater.

It's important to point that generalization of the results obtained should be cautious, due to the limitations in its method. Only university students were used, and their job preferences may change over time, as well as their interest in entrepreneurial behavior accordingly. Additionally, there was no variability in terms of age and educational level, as such, results may not be generalizable. For future research, it would be convenient to consider a larger, stratified, sample, using different regions and variable characteristics. Likewise, longitudinal studies should be considered to further understand the evolution of culture on entrepreneurial intention.

As final word, it's important to further explore aspects of the relationship that subjective norm, through culture, has on entrepreneurial intention at a contextual level. As this study showed, generalized models do not pertain to all specifics, and further research should be done to deepen the understanding of their interactions with different variables, including environment, to better assess the promotion and development of entrepreneurship in each respective situation. 
Sánchez-García, J.C., Ward Mayens, A., Vargas Morúa, G., Hernández Sánchez, B. (2018). How does Cultural Norms Influence Entrepreneurial Intention? A Cross Cultural Study. Journal of Business, Universidad del Pacífico (Lima, Peru) Vol.10 (1): 52-69

\section{References}

Ajzen, I. (1988). Attitude, Personality, and Behavior. Open University Press, Milton Keynes, Buckikngham.

Ajzen, I. (1991). The theory of planned behavior. Organizational behavior and human decision processes, 50(2), 179-211.

Ajzen, I. (2002). Perceived behavioral control, self-efficacy, locus of control, and the theory of planned behavior, Journal of Applied Social Psychology, 32, 665-683.

Ajzen, I., \& Fishbein, M. (2000). Attitudes and the attitude-behavior relation: Reasoned and automatic processes. European review of social psychology, 11(1), 1-33.

Aldrich, H. E., \& Cliff, J. E. (2003). The pervasive effects of family on entrepreneurship: Toward a family embeddedness perspective. Journal of business venturing, 18(5), 573596.

Armitage, C. J., \& Conner, M. (2001). "Efficacy of the theory of planned behavior: A meta analytic review". British Journal of Social Psychology, 40, 471-499.

Autio, E. H., Keeley, R., Klofsten, M., GC Parker, G., \& Hay, M. (2001). Entrepreneurial intent among students in Scandinavia and in the USA. Enterprise and Innovation Management Studies, 2(2), 145-160.

Bosma, N., Acs, Z. J., Autio, E., Coduras, A., and Levie, J. (2008): Global Entrepreneurship Monitor. 2008 executive report, Global Entrepreneurship.

Research Consortium (GERA), Wellesley, Massachusetts and London.

Bretones, F. D. y Silva, M. (2009). Cultura, sociedad, educación y comportamiento emprendedor. En F.D. Bretones (coord.) Comportamiento emprendedor en el ámbito universitario: personas y sociedad, 93-109. Granada: Editorial de la Universidad de Granada.

Bureau, P. (2015). Population Bulletien (Vol. 70).

Cabana-Villca, R; Cortes-Castillo, I; Plaza-Pasten, D; Castillo-Vergara, M; AlvarezMarin, A (2013). Análisis de Las Capacidades Emprendedoras Potenciales y Efectivas en Alumnos de Centros de Educación Superior. Journal of Technology Management \& Innovation, 8(1), 65-75.

Carr, J. C., \& Sequeira, J. M. (2007). Prior family business exposure as intergenerational influence and entrepreneurial intent: A theory of planned behavior approach. Journal of Business Research, 60 (10), 1090-1098

Díaz-Casero, J. C., Ferreira, J. J., M., Hernández Mogollón, R., \& Barata Raposo, M. L. (2012). Influence of institutional environment on entrepreneurial intention: A comparative study of two countries university students. International Entrepreneurship and Management Journal, 8(1), 55-74.

do Paço, A. M. F., Ferreira, J. M., Raposo, M., Gouveia, R. G., \& Dinis, A. (2011). Behaviours and entrepreneurial intention: Empirical findings about secondary students. Journal of International Entrepreneurship, 9(1), 20-38. 
Sánchez-García, J.C., Ward Mayens, A., Vargas Morúa, G., Hernández Sánchez, B. (2018). How does Cultural Norms Influence Entrepreneurial Intention? A Cross Cultural Study. Journal of Business, Universidad del Pacífico (Lima, Peru) Vol.10 (1): 52-69

Fayolle, A., Gailly, B., \& Lassas-Clerc, N. (2006). Assessing the impact of entrepreneurship education programmes: a new methodology. Journal of European industrial training, 30(9), 701-720.

Fisbein, M. \& Ajzen, I. (1975). Belief, Attitude, Intention, and Behavior: An Introduction to Theory and Research. Reading, MA: Addison Wesley.

Franco, M., Haase, H., \& Lautenschläger, A. (2010). Students' entrepreneurial intentions: an inter-regional comparison. Education+ Training, 52(4), 260-275.

Global Entrepreneurship Monitor Consortium (2013). Global Entrepreneurship Monitor: National Reports, Portugal. Retrieved November 9, 2017 at http://www.gemconsortium.org/report/49189.

Global Entrepreneurship Monitor Consortium (2015). Global Entrepreneurship Monitor: Global Report 2015-2016.

Global Entrepreneurship Monitor Consortium (2016). Global Entrepreneurship Monitor: Global Report 2016-2017.

Guido, G., Marcati, A., \& Peluso, A. M. (2011). "Nature and antecedents of a marketing approach according to Italian SME entrepreneurs, A structural equation modeling approach". International Journal of Entrepreneurial Behaviour \& Research, 17(4), 342360.

Harris, M. L., \& Gibson, S. G. (2008). Examining the entrepreneurial attitudes of US business students. Education \& Training, 50(7), 568-581

Hayes, A. F., \& Scharkow, M. (2013). The relative trustworthiness of inferential tests of the indirect effect in statistical mediation analysis: Does method really matter? Psychological Science, 24(10), 1918-1927.

Hayes, A. F., \& Preacher, K. J. (2014). Statistical mediation analysis with a multicategorical independent variable. British Journal of Mathematical and Statistical Psychology, 67(3), 451-470. https://doi.org/10.1111/bmsp.12028

Hechavarria, M., \& Reynolds, P. (2009). Cultural norms \& business startup: The impact of national values on opportunity and necessity entrepreneurs. International Entrepreneurship and Management Journal, 5, 417-437.

Homer, P M., \& Kahle, L.R. (1988). A structural Equation test of the value attitudebehavior hierarchy. Journal of Personality and Social Psychology, 54(4), 638-646.

Hofstede, G. (1980): Motivation, Leadership, and Organization: Do American Theories Apply Abroad? Organizational Dynamics, 9(1), 42-63.

lakovleva, T., Kolvereid, L. \& Stephan, U. (2011). Entrepreneurial intentions in developing and developed countries. Education+ Training, 53(5), 353-370.

Jogiyanto, (2007) Sistem Informasi Keperilakuan, Yogyakarta, Andi Publisher.

Kautonen, T., Luoto, S., \& Tornikoski, E. T. (2010). Influence of work history on entrepreneurial intentions in 'prime age' and 'third age': A preliminary study. International small business journal, 28(6), 583-601. 
Sánchez-García, J.C., Ward Mayens, A., Vargas Morúa, G., Hernández Sánchez, B. (2018). How does Cultural Norms Influence Entrepreneurial Intention? A Cross Cultural Study. Journal of Business, Universidad del Pacífico (Lima, Peru) Vol.10 (1): 52-69

Kolvereid, L. (1996). "Prediction of Employment status choice intentions". Entrepreneurship Theory \& Practice, 21(1). 47-57.

Krueger, N. F., \& Brazeal, D. V. (1994). Entrepreneurial potential and potential entrepreneurs. Entrepreneurship theory and practice, 18, 91-91.

Krueger, N. F., \& Carsrud, A. L. (1993). Entrepreneurial intentions: applying the theory of planned behaviour. Entrepreneurship \& Regional Development, 5(4), 315-330.

Krueger, N. F., Reilly, M. D., \& Carsrud, A. L. (2000). Competing models of entrepreneurial intentions. Journal of business venturing, 15(5), 411-432.

Le, A. T. (1999). Empirical studies of self-employment. Journal of Economic surveys, 13(4), 381-416.

Liñan, F. (2008). Skill and value perceptions: how do they affect entrepreneurial intentions? International Entrepreneurship and Management Journal, 4(3), 257-272.

Liñan, F., \& Chen, Y. W. (2009). "Development and cross-cultural application of a specific instrument to measure entrepreneurial intention". Entrepreneurship theory and practice, 33(3), 593-617.

Manolova, T.S., Eunni, R.V., \& Gyoshev, B.S. (2008). Institutional environments for entrepreneurship: evidence from emerging economies in Eastern Europe. Entrepreneurship Theory \& Practice, 31(1), 203-218.

Miner, J. B. (2001). Industrial Organizational Psychology, New York, McGraw-Hill.

Mohamed, Z., Rezai, G., Mad, N. S., \& Muhammad Mu'az Mahmud (2012). Enhancing young graduates' intention towards entrepreneurship development in Malaysia. Education \& Training, 54(7), 605-618.

Mueller, S. L., \& Thomas, A. S. (2001). Culture and entrepreneurial potential: A nine country study of locus of control and innovativeness. Journal of business venturing, 16(1), 51-75.

Nilsson A., Borgstede, C. V., \& Biel, A. (2004). Willingness to accept climate change strategy: The effect values and norms. Journal of environmental Psychology, 24(3), 267277.

Oficina Económica y Comercial de España. (2016). Informe económico y comercial. Ministerio de Economía Industria $Y$ Competitividad, 99. Retrieved from http://www.comercio.gob.es/tmpDocsCanalPais/D8DA906424E80E4A58A6F960100C9 E63.pdf

Paul, J., \& Gupta, P. (2014). Process and intensity of internationalization of IT firmsEvidence from India. International Business Review, 23(3), 594-603.

Paul, J., Hermel, P., \& Srivatava, A. (2017). Entrepreneurial intentions-theory and evidence from Asia, America, and Europe. Journal of International Entrepreneurship, 15(3), 324-351.

Peterman, N. E., \& Kennedy, J. (2003). Enterprise education: Influencing students' perceptions of entrepreneurship. Entrepreneurship theory and practice, 28(2), 129-144. 
Sánchez-García, J.C., Ward Mayens, A., Vargas Morúa, G., Hernández Sánchez, B. (2018). How does Cultural Norms Influence Entrepreneurial Intention? A Cross Cultural Study. Journal of Business, Universidad del Pacífico (Lima, Peru) Vol.10 (1): 52-69

Prieto, L., Wang, L., Hinrichs, K. T., \& Aguirre-Milling, H. (2010). Propensity for selfemployment: contrasting the USA and Mexico. Journal of Small Business and Enterprise Development, 17(3), 315-333.

Rhodes, R, E., \& Courneya, K. S. (2003). Investigating multiple components of attitude, subjective norms, perceived control: An examination the theory of planned behavior in the exercise domain. British journal of social psychology, 23(42),129-146.

Rimal, R. N., \& Real, K. (2003). Understanding the influence of perceived norms on behaviors. International Communication Association.

Sánchez, J. and Yurrebaso, A. (2008). Are young Mexicans more entrepreneurial than Spanish and Portuguese? The role of the self-reinforcing property of entrepreneurship, RENT XXII-Research in Entrepreneurship and Small Business, Covilhã, Portugal. November 20-21.

Sánchez, J. (2009). Aprendizaje social e intenciones emprendedoras: un estudio comparativo entre México, España y Portugal. Revista Latinoamericana de Psicología, 41 (1), 109-119.

Sánchez, J. C. (2010). Evaluación de la personalidad emprendedora: Validez factorial del cuestionario de orientación emprendedora (COE). Revista Latinoamericana de Psicología, 42(1), 41-52.

Sampedro, I. R., Fernández-Laviada, A., \& Crespo, Á. H. (2013). Aplicación de la teoría de la acción razonada al ámbito emprendedor en un contexto universitario/Applying the theory of reasoned action to entrepreneurship within a university setting. Investigaciones Regionales, 26, 141-158.

Shapero, A., \& Sokol, L. (1982). The social dimensions of entrepreneurship. Encyclopedia of entrepreneurship, 72-90.

Shaw, E., \& de Bruin, A. (2013). Reconsidering capitalism: the promise of social innovation and social entrepreneurship? International Small Business Journal, 31(7), 737-746.

Scholten, V., Kemp, R. y Omta, S. W. F., (2004). Entrepreneurship for life: The entrepreneurial intention among academics in the life sciences. European Summer University Conference, pp.1-15.

Shook, C., \& Bratianu, C. (2010). "Entrepreneur intent in a transitional economy: An application of the theory of planned behavior to Rumanian student". International Entrepreneurship and Management Journal, 6, 231-247.

Schwarz, E. J., Wdowiak, M. A., Almer-Jarz, D. A., \& Breitenecker, R. J. (2009). "The effects on attitudes and perceived environment conditions on students' entrepreneurial intent: An Austrian perspective". Education + Training. 51(4), 272-291.

Solesvick, M. Z., Westhead, P., Kolvereid, I., \& Matlay, H. (2012). Student intentions to become self-employed: The Ukrainian context. Journal of Small Business and Enterprise Development, 19(3), 441-460. 
Tiwari, P., Bhat, A. K., \& Tikoria, J. (2017). An empirical analysis of the factors affecting social entrepreneurial intentions. Journal of Global Entrepreneurship Research, 7(1), 125.

Tkachev, A. \& Kolvereid, L (1999). "Self-employment intentions among Russian students". Entrepreneurship and Regional Development. 11(3), 269 -80.

Tornikoski, E. T., Erno T., \& Kautonen, T. (2009). Enterprise in Sunset Career? Entrepreneurial Intentions in the Ageing Population. International Journal of Entrepreneurship and Small Business, 8(2), 278- 291.

Uslay, C., Teach, R. D., and Schwartz, R. G. (2002): "Promoting Entrepreneurship for Economic Development: A Cross-Cultural Analysis of Attitudinal Differences About Entrepreneurship", Journal of Research in Marketing and Entrepreneurship, 4(2), 101118.

Williams, C. (2009). The motives of off-the-books entrepreneurs: necessity-or opportunity-driven? International Entrepreneurship and Management Journal, 5, 203217.

Wilson, F., Kickul, J., \& Marlino, D. (2007). Gender, entrepreneurial Self-Efficacy, and entrepreneurial career intentions: Implications for entrepreneurship Education1. Entrepreneurship theory and practice, 31(3), 387-406.

Zhang, Y., Duysters, G., \& Cloodt, M. (2014). The role of entrepreneurship education as a predictor of university students' entrepreneurial intention. International Entrepreneurship and Management Journal, 10(3), 62. 